\title{
コジュケイの異常距に就いて
}

\section{On an abnormal spur in Chinese Bamboo Pheasant.}

\author{
白井邦彥
}

Kunihiko Shirai

䳝秤目 Galli 鳥類からは，霓々距の異常な個体が発見されるものである が，筆者は, コジュケイ Bambusicola t. thoracica (Temminck) にぬ， 異常距のあることを承知したので，玆に報告する。

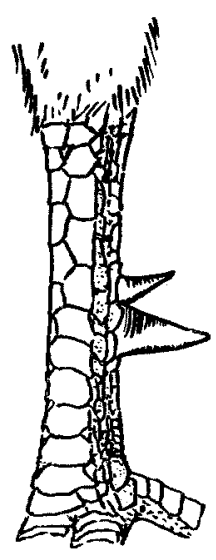

II 捕獲者 同県同郡同町字大越路; 水越隆平氏 北京す。(単位 $\mathrm{mm}$ ) つた。 りである。

附図に示すように，これは距が両脚に夫々 2 個宛存在す る二重距である。即ち正常距に接してその上部に，更に 一個の異常距が発生しているのである。距の大きさは下表

この個体は，コジュケイ属Bambusicola の二重距とし て最初の標本と思われる。本個体の羽色は正常であり, 距 が 2 個宛存在する以外は正常である。然して解剖的所見 む, 生殖器官その他に就いて, 何等の異状は見られなか

次に, この個体が捕獲された状況を附記すると, 次の通

I 捕獲地 山梨県北都留郡上野原町字石舟

\begin{tabular}{|c|c|c|c|c|c|c|}
\hline & & 正 & 常 & 距 & 異 & 常 \\
\hline 外 & 側 & & 7.5 & & & 4.5 \\
\hline 内 & 側 & & 8.5 & & & 5.5 \\
\hline
\end{tabular}

III 捕獲期日と天候 昭和 26 年 (1951) 2 月 26 日午後 4 時; 午前中 約 $60 \mathrm{~mm}$ の降雪があり，午後は曇天が続いていた。 
IV 捕獲法 ウキリアム・エヴアンス 20 番 2 連散彈銃にウエスタン・ スーパーX $23 / 4$ インチ薬夾 8 男装彈を用い，仯犬に追出させて射酸し た。

$\mathrm{V}$ 捕獲地の環境 山梨具北都留郡上野原町から同町字奈須部を経て, 神 奈川県津久井郡佐野川村方面へ通ずる小径を迎ると，小川(後山川という)が ありこれに木橋(後川橋という)が架設されている。この橋の上流約 $300 \mathrm{~m}$ の地点が捕獲地である。現場の環境は，右岸が水田でその間国に的 $20 \mathrm{~m}$ 位 の篠藪が存在し，左岸は篠の混した雑木林の傾斜地（約 $40^{\circ}$ 位）となつてい る。傾斜地の上方は広い麦皇が転開している。

VI 本個体所属群の員数 捕獲せられた個体の所属する群の個員は，昭和 25 (1950) 年 11 月には12〜3 羽の員数を数えていたが，次第に減数して 当日は 6 羽となつていた。

擱筆に当り，本個体を恵贈せられた水越隆平氏と，插図を画いていただい た三島冬嗍氏とに感謝する。

\section{Résumé}

An example of double spurred Bambusicola thoracica thoracica (Temminck), shot at Uenohara-machi, Yamanashi, Prefecture, February 26, 1951, is reported. This may be the first case in this genus. 